\title{
STUDI KRITIS TERHADAP RAGAM KONSEP NEGARA HUKUM
}

\author{
Ramli $^{1}$ \\ Staf Pengajar Fakultas Hukum Universitas Mahasaraswati Mataram \\ Email: Ramliunmas@gmail.com \\ Muhammad Afzal ${ }^{2}$ \\ Email: afzalalex369@gmail.com \\ Staf Pengajar Fakultas Hukum Universitas Mahasaraswati Mataram \\ Gede Tusan Ardika ${ }^{3}$ \\ Staf Pengajar Fakultas Hukum Universitas Mahasaraswati Mataram \\ Email: gedetusanardika@gmail.com \\ DOI: https://doi.org/10.31764/mk:\%20jih.v10i2.1969
}

Received: Mei 22, 2019, Accepted: Agst 20, 2019 /Published: Okt 31, 2019

\begin{abstract}
Indonesia is a state of law as stipulated in article 1 number 3 of the 1945 Constitution. Indonesia is one of the countries in the world, which is a state of law. Indonesia's position as a state of law has very broad implications in various other fields. The reality of Indonesian society's life cannot be separated from the existence of the law inherent in a multi-ethnic, multi-cultural society. The term legal state (Rechstaat) is no stranger to constitutional knowledge from ancient times to the present. It's just that in the practice of state administration people are still witnessing whether the rule of law has been fully implemented or not. This research is a type of normative research, and uses descriptive qualitative analysis through critical studies. The results of this study indicate that the concept of rechstaat prioritizes the wetmatigheid principle which then becomes the rechtmatigheid. Elements of Rechstsst: 1) The existence of protection of human rights, 2) The separation and distribution of state power to guarantee the protection of human rights, 3) Governance based on regulations, and 4) The existence of administrative justice. However, the implementation of the said rule of law has not yet been implemented well and comprehensively

Keywords: Critical Study, Variety of Concepts, State, Law
\end{abstract}

\begin{abstract}
ABSTRAK
Indonesia ialah negara hukum sebagaimana tertuang dalam pasal 1 angka 3 Undang-undang Dasar Tahun 1945. Indonesia sebagai salah satu negara di dunia, yang merupakan negara hukum. Kedudukan Indonesia sebagai sebuah negara hukum, membawa implikasi yang sangat luas pada berbagai bidang lain. Realitas kehidupan masyarakat Indonesia yang tidak bisa dilepaskan dari keberadaan hukum yang melekat pada masyarakat yang multi-etnis, multi-kultural. Istilah negara hukum
\end{abstract}


(Rechstaat) tidak asing lagi dalam pengetahuan ketatanegaraan sejak zaman purba hingga sekarang ini. Hanya saja dalam praktek ketatanegaraan, orang masih menyaksikan apakah negara hukum itu sudah dilaksanakan sepenuhnya atau tidak. Penelitian ini merupakan jenis penelitian normatif, dan menggunakan analisis deskriptif kualitatif melalui studi hukum kritis. Hasil penelitian ini menunjukkan bahwa Konsep rechstaat mengutamakan prinsip wetmatigheid yang kemudian menjadi rechtmatigheid. Unsur-unsur rechstaat: 1) adanya perlindungan terhadap hak-hak asasi manusia (HAM), 2) adanya pemisahan dan pembagian kekuasaan negara untuk menjamin perlindungan HAM, 3) pemerintahan berdasarkan peraturan, dan 4) adanya peradilan administrasi. Akan tetapi pada aspek implementatif negara hukum dimaksud belum terlaksana dengan baik dan komprehensif

Kata kunci: hukum, negara, ragam konsep, studi kritis

\section{PENDAHULUAN}

Indonesia ialah negara hukum sebagaimana tertuang dalam pasal 1 angka 3 Undang-undang Dasar Tahun 1945. ${ }^{1}$ Indonesia adalah salah satu negara di dunia ini yang merupakan negara hukum. Kedudukan Indonesia sebagai sebuah negara hukum, membawa implikasi yang sangat luas pada berbagai bidang lain. Realitas kehidupan masyarakat Indonesia yang tidak bisa dilepaskan dari keberadaan hukum yang melekat pada masyarakat yang multi-etnis, multi-kultural. Istilah negara hukum (Rechstaat) tidak asing lagi dalam pengetahuan ketatanegaraan sejak zaman purba hingga sekarang ini. Hanya saja dalam praktek ketatanegaraan orang masih menyaksikan apakah negara hukum itu sudah dilaksanakan sepenuhnya.

Negara hukum adalah negara berdasarkan atas hukum dan keadilan bagi warganya. Artinya adalah segala kewenangan dan tindakan alat-alat perlengkapan negara atau dengan kata lain diatur oleh hukum. Hal demikian akan mencerminkan keadilan bagi pergaulan hidup warganya. ${ }^{2}$

1 Pasal 1 Ayat (3) Undang-undang Dasar Tahun 1945

2 Abdul Aziz Hakim, Negara Hukum dan Demokrasi, Pustaka Pelajar, Yogyakarta. 2011, Hal.8 
Perkiraan negara hukum dimulai sejak plato dengan konsepnya "bahwa penyelenggaraan negara yang baik adalah didasarkan pada pengaturan (hukum) yang baik yang disebut dengan istilah "nomoi". Kemudian ide tentang negara hukum populer pada abad ke-17 sebagai akibat dari situasi politik di eropa yang didominasi oleh absolutisme. Dalam perkembangannya, paham negara hukum tidak dapat dipisahkan dari paham kerakyatan. Sebab pada hakikatnya, hukum yang mengatur dan membatasi kekuasaan negara atau pemerintah diartikan sebagai hukum yang dibuat atas dasar kekuasaan dan kedaulatan rakyat. Dalam kaitannya dengan negara hukum, kedaulatan rakyat merupakan unsur material negara hukum. Disamping masalah kesejahtraan rakyat. ${ }^{3}$

Salah satu asas penting negara hukum adalah asas legalitas. Asas legalitas berkaitan erat dengan gagasan demokrasi dan gagasan negara hukum. Gagasan demokrasi menuntut agar setiap bentuk undang-undang dan berbagai keputusan pendapat persetujuan dari wakil rakyat dan sebanyak mungkin memperhatikan kepentingan rakyat. Gagasan negara hukum menuntut agar penyelenggaraan kenegaraan dan pemerintah harus pada undang-undang dan memberikan jaminan terhadap hak-hak dasar rakyat yang tertuang dalam undang-undang. Menurut Sjachran Basah, asas legalitas berarti upaya mewujudkan duet integral secara harmonis antara paham kedaulatan hukum dan paham kedaulatan rakyat berdasarkan prinsip monodualitas selaku pilar-pilar, yang sifat hakikinya konstitutif.

Istilah negara hukum baru dikenal pada abad XIX tetapi konsep negara hukum telah lama ada dan berkembang sesuai dengan tuntunan keadaan. Pemerintahan berdasarkan hukum adalah suatu prinsip dimana

${ }^{3}$ Ni Matul Huda, Negara Hukum dan demokrasi \& Judicial Review, UII Press, Yogyakarta. 2005. Hal.9 
menyatakan bahwa hukum adalah otoritas tertinggi dan bahwa semua warga negara tunduk kepada hukum dan berhak atas perlindungannya. Secara sederhana supermasi hukum bisa dikatakan kekuatan pihak yang kuat diganti dengan kekuasaan berdasarkan keadilan dan rasional.

Konsep negara hukum menurut M. Yamin, sebenarnya sudah ada beribu-ribuan tahun sebelum proklamasi kemerdekaan Republik Indonesia Tahun 1945, yang menjadi hukum secara tertulis di Republik Indonesia. Istilah negara hukum jauh lebih muda daripada pengertian negara hukum yang dikenal dalam negara-negara di wilayah Indonesia, seperti sriwijaya, majapahit, melayu, minangkabau dan mataram. Hasil penyelidikan ini menolak pendapat seolah-olah pengertian negara hukum semata-mata bersumber atau berasal dari hukum Eropa Barat.

Dari pengertian negara hukum sebagaimana dikemukakan di atas, dapat disimpulkan bahwa negara hukum sebagai suatu konsep sebenarnya tidak terbatas pada perkembangan negara modern. Sebab dalam masyarakat, baik pada masyarakat yang perkembangannya sudah sangat tinggi, selalu terdapat hukum. Menurut salah satu filosof Yunani kuno Cicero, yang mengatakan bahwa ubi society ubi ius yang artinya dimana ada masyarakat, disitu ada hukum. Dari pendapat tersebut dapat memberikan gambaran bahwa pada setiap masyarakat manusia, lepas dari persoalan seberapa sederhana keadaannya atau seberapa tinggi kemajuannya, pasti terdapat hukum kendati pun corak atau kerumitan dari hukum yang ada dan berlaku memang berbeda-beda pada masyarakat-masyarakat yang berbeda tingkat kemajuannya, namun tetaplah disitu ada hukum. Penerapan asas legalitas menurut Indroharto, akan menunjang berlakunya kepastian hukum dan berlakunya kesamaan perlakuan. 4

\footnotetext{
${ }^{4}$ Ibid.
} 


\section{METODOLOGI}

Dalam penelitian ini jenis penelitian yang digunakan adalah penelitian hukum normatif, dengan menggunakan analisis deskriptif kualitatif melalui studi hukum kritis. Penelitian hukum normatif disebut juga dengan penelitian doktrinal, dalam penelitian ini acapkali hukum dikonsepkan sebagai apa yang tertulis dalam peraturan perundangundangan (law in book) atau hukum dikonsepkan sebagai sebagai kaedah atau norma yang merupakan patokan berprilaku bagi manusia yang dianggap pantas. ${ }^{5}$

\section{PEMBAHASAN}

\section{A. Sejarah dan Perkembangan Negara Hukum}

Pemikiran tentang negara hukum telah jauh muncul sebelum terjadinya revolusi 1688 di inggris, tetapi baru muncul kembali pada abad XVII dan populer pada abad XIX. Pemikiran negara hukum itu sendiri adalah sebuah reaksi akibat kesewenang-wenangan di masa lampau. Maka dari itu unsur-unsur negara hukum mempunyai hubungan yang erat dengan sejarah dan perkembangan masyarakat suatu bangsa. ${ }^{6}$

Ditinjau dari perspektif historis, perkembangan pemikiran filsafat hukum dan kenegaraan mengenai negara hukum sudah berkembang sejak tahun 1800 SM. Menurut Jimli Asshidiqie akal sejauh pemikiran negara hukum adalah pada masa yunani kono. Menurut beliau gagasan kedaulatan rakyat tumbuh dan berkembang dari tradisi romawi, sedangkan tradisi yunani kuno menjadi sumber dari gagasan kedaulatan hukum.

Salah satu persoalan pokok negara hukum adalah persoalan kekuasaan. Secara historis persoalan kekuasaan telah muncul sejak

5 Amirudin dan Zaenal Asikin, Pengantar Metode Penelitian Hukum, PT Rajawali Grafindo Persada. Jakarta. 2004, Hal. 118

${ }^{6}$ Ni Matul Huda, Op.Cit. Hal.2 
zaman Plato dengan menempatkan kekuasaan sebagai sarana untuk menegakkan hukum dan keadilan. Sejak itu, hukum dan keadilan dihadapkan dengan kekuasaan. ${ }^{7}$

Plato dan Aristoteles mengintrodusir negara hukum adalah negara yang diperintah oleh negara yang adil. Dalam filsafatnya, keduanya menyinggung angan-angan (cita-cita) manusia yang berkorespondensi dengan dunia, dengan mutlak yang disebut: ${ }^{8}$

a. Cita-cita untuk mengejar kebenaran

b. Cita-cita untuk mengejar keindahan

c. Cita-cita untuk mengejar keadilan

Plato dan Aristoteles menganut paham filsafat idealisme. Menurut Aristoteles, keadilan dapat berupa komutatif dan distributif. Menurut Plato yang kemudian dilanjutkan oleh Aristoteles, bahwa hukum yang diharapkan adalah hukum yang adil dan dapat memberikan kesejahteraan bagi masyarakat, hukum yang merupakan bukan paksaan dari penguasa melainkan sesuai dengan kehendak warga negara, dan untuk mengatur hukum itu dibutuhkan konstitusi yang memuat aturanaturan dalam hidup bernegara.

Pada masa Yunani Kuno pemikiran tentang negara hukum dikembangkan oleh para filsuf besar Yunani Kuno seperti Plato, dalam karya ketiganya nomoi, plato mengemukakan bahwa penyelenggaraan negara yang baik ialah yang didasarkan pada pengaturan (hukum) yang baik. ${ }^{9}$ Gagasan Plato tersebut semakin tegas ketika didukung oleh muridnya, Aristoteles, dalam bukunya politica menyatakan bahwa suatu negara yang baik ialah negara yang diperintah dengan konstitusi dan kedaulatan hukum. Menurut Aristoteles terdapat tiga unsur

\footnotetext{
7 S.F Marbun, Peradilan Administratif Negara dan Upaya Administratif di Indonesia, UII Press, Yogyakarta, 2011, Hal.1

8 Moh. Kusnardi dan Bintan Saragih, Ilmu Negara. Gaya Media. Jakarta, 2000. Hal 131

9 Tahir Azhary, Negara Hukum, Bulan Bintang, Jakarta, 1992, Hal. 66
} 
pemerintahan yang berkonstitusi, yaitu: pertama, pemerintahan dilaksanakan untuk kepentingan umum. Kedua, pemerintahan dilaksanakan menurut hukum yang berdasarkan pada ketentuanketentuan umum, bukan hukum yang dibuat secara sewenang-wenang yang menyampingkan konvensi dan konstitusi. Ketiga, pemerintahan yang berkonstitusi adalah pemerintahan yang dilaksanakan atas kehendak rakyat, bukan berupa paksaan.

Pada abad pertengahan, ide negara hukum muncul untuk membendung adanya kesewenang-wenangan dari kekuasaan yang memperaktikan sistem yang absolute dan mengabaikan hak-hak dari rakyat. Peristiwa revolusi Prancis merupakan sebuah pelajaran nyata yang sangat berharga untuk direnungkan. Absolutisme di Prancis yang dilakukan oleh raja Louis XIV dengan sabda rajanya yang fenomenal. Sabda raja tersebut melahirkan semboyan " $I$ " etat " $e$ " est moi" yang berarti negara adalah saya. ${ }^{10}$

Sikap raja yang absolute menyebabkan bangkitnya gerakangerakan menentang raja. Terbukti seiring perjalanan waktu, peralihan masyarakat agraris ke masyarakat industri atau terjadinya revolusi industri melalui proses transformasi yang panjang (1750-1850) melahirkan para pebisnis atau kaum kapitalis yang juga menggugat absolutisme raja.

Imanuel Kant mengemukakan paham negara hukum dalam arti sempit, bahwa negara hanya sebagai perlindungan hak-hak individual. Sedangkan kekuasaan negara diartikan secara pasif, bertugas memelihara ketertiban dan keamanan masyarakat.

\section{B. Konsep Negara Hukum}

Dalam penjelasan umum UUD 1945 disebutkan bahwa “Indonesia adalah negara yang berdasarkan atas hukum, tidak atas kekuasaan belaka.

10 Sugan, Wirananggapati dkk, Sejarah Nasional Indonesia dan Dunia. PT Galaxy Puspa Mega. Jakarta. 1992. Hal. 2 
Ketentuan ini dipertegas kembali dalam pasal 1 ayat (3) amandemen ke 3 (tiga) Undang-Undang Dasar 1945 tyang menyebutkan bahwa negara Indonesia adalah negara hukum.

Berbicara tentang negara hukum, para ahli memberikan pengertian yang berbeda-beda. Mochtar Kusumaatmadja memberikan pengertian negara hukum sebagai "negara yang berdasarkan hukum dimana kekuasaan tunduk pada hukum dan semua orang yang sama dihadapan hukum. ${ }^{11}$ Menurut Hamid S. Attamimi Begara hukum adalah negara yang menempatkan hukum sebagai dasar kekuasaan negara dan penyelenggara kekuasaan negara tersebut dalam segala bentuknya dilakukan dibawah kekuasaan hukum. ${ }^{12}$

Dari pengertian di atas dijelaskan bahwa sesungguhnya tidak ada keseragaman pengertian tentang istilah negara hukum itu. Meskipun demikian, dari ketiga pengertian tersebut dapat diketahui bahwa, istilah negara hukum yang banyak dijumpai dalam kepustakaan Indonesia menunjuk pada suatu konsep tentang negara dimana pemerintah atau penguasa, dalam menjalankan kekuasaannya harus berdasarkan pada hukum dan tidak didasarkan atas kemauannya semata.

\section{Negara Hukum Rechsstaat}

Beberapa pakar memberikan pandangannya mengenai konsep rehtsstaat antara lain Immanuel Kant. Kant memahami rehtsstaat sebagai negara penjaga malam yang tugasnya menjamin keamanan dan ketertiban masyarakat. Gagasan kant ini dinamakan negara hukum liberal. Tugas negara tidak cukup hanya melindungi hak dan kebebasan warganya, juga tidak cukup hanya menjaga tertib hukum, melainkan negara harus mengurus kesejahtraan rakyatnya.

11 Mochtar, Kusumaatmadja, Pemantapan Cita Hukum dan Asas-asas Hukum Nasional di Masa Kini dan Masa yang Akan Datang, Jakarta, 1995, Hal 1.

12 Sudargo, Gautama, Pengertian tentang Negara Hukum, Alumni, Bandung, 1983, Hal 21. 
Selanjutnya cita negara hukum disempurnakan oleh sarjana Jerman Friedich Julius Stahl. Menurut F.J. Stahl, rechtsstaat memiliki unsur yaitu:

a. Pengakuan dan perlindungan terhadap hak-hak asasi manusia

b. Pemisahan kekuasaan negara berdasarkan prinsip trias politica

c. Pemerintahan diselenggarakan berdasarkan undang-undang

d. Adanya peradilan administrasi negara yang bertugas menangani kasus perbuatan melanggar hukum oleh pemerintah.

\section{D.Negara Hukum Rule of Law}

Konsep rechtsstaat bukan satu-satunya konsep tentang negara hukum. Di inggris dikenal konsep negara hukum yang disebut rule of law. Negara hukum berdasarkan konsep rechtsstaat umumnya berkembang di negara-negara eropa kontinental, sedangkan di negara-negara anglo saxon, pemahaman terhadap negara hukum mengikuti konsep rule of law yang dipelopori oleh Albert Venn Dicey tahun 1885 dalam bukunya yang berjudul introduction to the study of law of the constitution.

Tiga unsur utama negara hukum berdasarkan konsep rule of law adalah, unsur yang pertama, yaitu supremacy of law atau supremasi hukum. Di Inggris, ini merupakan hal yang tidak dapat ditawar-tawar lagi. Merupakan unsur yang diperjuangkan rakyat Inggris lebih awal jika dibandingkan dengan negara-negara barat lainnya. Negara Inggris yang diatur oleh hukum dan seorang hanya mungkin dihukum karena melanggar hukum, dan tidak karena hal-hal lainnya. Hak kebebasan seseorang benar-benar dijamin oleh hukum, artinya tidak seorang pun boleh dipenjarakan atau ditahan tanpa adanya dasar hukum atau hukum yang dilanggarnya. ${ }^{13}$

Unsur kedua, yaitu equality before the law atau persamaan di muka hukum. Semua warga, baik selaku pejabat negara maupun sebagai

${ }^{13}$ Koko Kosidin, "Perlindungan Hukum bagi Tenaga Kerja di Indonesia", Disertasi Universitas Padjajaran, Bandung , 1997, Hal. 50. 
individu biasa tunduk pada hukum yang sama dan diadili di pengadilan biasa yang sama. Jadi setiap warga Negara, sama kedudukannya di hadapan hukum dan apabila ia melanggar hukum baik selaku pribadi atau individu maupun selaku pejabat negara, ia akan diadili dengan hukum yang sama dan dalam pengadilan yang sama pula. Dengan demikian di Inggris tidak dikenal pengadilan khusus bagi pejabat negara seperti dikenal dalam sistem hukum eropa kontinental yang berupa pengadilan administrasi.

Unsur ketiga, yaitu constitution base on individual rights. Constitution disini tidak seperti yang umum terdapat di negara lain yang berupa sebuah dokumen yang disebut constitution atau Undang-Undang Dasar. Yaitu constitution menunjuk pada sejumlah dokumen yang isinya bersifat fundamental. Dijadikan dasar oleh rakyat Inggris di dalam menata kehidupan berbangsa dan bernegara.

\section{E. Negara Hukum Pancasila}

Di dalam Undang-Undang Dasar 1945 sebelum amandemen, baik dalam pembukaan, batang tubuh maupun pasal-pasalnya tidak ditemukan rumusan negara hukum. Namun dalam penjelasannya disebutkan bahwa "negara Indonesia berdasar atas hokum". Adanya kata rechtsstaat tidek serta merta negara hukum Indonesia berdasarkan konsep tersebut. Fakta sejarah memang tidak bisa dipungkiri bangsa Indonesia dijajah Belanda dalam waktu yang cukup lama yakni 3,5 abad, sehingga tidak bisa dihindari adanya konsep-konsep hukum Belanda yang diadopsi dalam membangun sistem hukum dan/atau ketatanegaraan Indonesia.

Menurut Daniel S. Lev konsep rechtsstaat diantara tanda kurung dalam penjelasan Undang-Undang Dasar 1945 merupakan terminologi yang lazim digunakan di negara-negara eropa kontinental misalnya Jerman dan Belanda. Digunakannya terminologi tersebut dalam penjelasan UUD 1945 menandakan bahwa konsep negara hokum Indonesia dipengaruhi 
oleh paham anglo saxon the rule of law dan eropa kontinental "rechtsstaat". Pengaruh kedua konsep tersebut diakui Padmo Wahyono dengan mengatakan bahwa Indonesia adalah negara yang berdasarkan atas hukum, dengan rumusan "rechtsstaat" diantara kurung, dengan anggapan bahwa pola yang diambil tidak menyimpang dari pengertian negara hukum pada umumnya disesuaikan dengan keadaan di Indonesia. Artinya digunakan dengan ukuran pandangan hidup maupun pandangan hidup maupun pandangan bernegara kita.

Pengaruh kedua konsep tersebut dapat dilihat dari adanya pengadilan tata usaha negara (PTUN) untuk menguji keabsahan keputusan tata usaha negara yang berkaitan dengan kepentingan rakyat. Hal tersebut mengadopsi sistem eropa kontinental, serta adanya pengaturan pasal 27 Undang-Undang Dasar 1945 yang menyatakan bahwa semua warga negara mempunyai kedudukan yang sama dalam hukum dan pemerintahan, menunjukkan bahwa konsepsi negara hukum berdasarkan tradisi anglo saxon berdasarkan asas rule of law juga mewarnai negara hukum Indonesia. Namun demikian, negara hukum Indonesia tidak identik dengan kedua konsep negara hukum tersebut. Penulis sependapat dengan pandangan Padmo Wahyono di atas, bahwa negara hukum Indonesia harus memenuhi unsur umum dari konsep sebuah negara hukum, baru kemudian dikemas sesuai dengan ciri khas bangsa Indonesia yang berdasarkan pada falsafah hidup Pancasila. Dari berbagai konsep negara hukum seperti disebut di atas, dapat ditarik beberapa unsur esensi dari negara hukum, yakni:

a. Pengakuan dan perlindungan terhadap hak-hak asasi manusia

b. Pemisahan dan pembagian kekuasaan negara berdasarkan prinsip trias politika

c. Asas legalitas termasuk didalamnya adanya konstitusi

d. Adanya peradilan yang bebas dan tidak memihak. 
Unsur pertama, pengakuan dan perlindungan terhadap hak asasi manusia merupakan salah satu ciri utama negara hukum yang demokratis. Setiap manusia memiliki seperangkat hak yang melekat pada hakekat dan keberadaan manusia sebagai mahluk Tuhan Yang Maha Esa dan merupakan anugrah-Nya yang wajib dihormati, dijunjung tinggi oleh negara, pemerintah dan setiap orang demi penghormatan serta perlindungan harkat dan martabat manusia. Penyelenggaraan pemerintahan suatu negara tidak boleh mengurangi arti dan makna hak asasi manusia tersebut.

Unsur kedua, pembagian kekuasaan negara dimaksudkan untuk menghindari penumpukan kekuasaan dalam satu tangan yang sangat cendrung pada penyalahgunaan kekuasaan, yang berarti pemerkosaan terhadap kebebasan dan persamaan. Di Indonesia kekuasaan menjalankan pemerintahan (eksekutif) dilakukan oleh presiden. Kekuasaan membuat Undang-undang (legislatif) berada pada DPR, dan kekuasaan kehakiman (yudikatif) berada pada mahkamah agung (MA). Unsur ketiga, asas legalitas yaitu segala tindakan pemerintah harus didasarkan pada konstitusi dan perundang-undangan yang sah. Peraturan perundangundangan tersebut harus ada dan berlaku terlebih dahulu sebelum perbuatan dilakukan. Unsur keempat, adanya peradilan yang bebas dan tidak memihak mutlak harus ada dalam negara hukum. Dalam menjalankan tugas judisialnya, hakim tidak boleh dipengaruhi oleh siapapun, karena kepentingan jabatan maupun kepentingan ekonomi.

Konsep negara hukum Pancasila merupakan konsep yang dikembangkan oleh para pakar hukum di Indonesia. Pada dasarnya konsep negara hukum ini selain memiliki unsur-unsur pada konsep negara hukum yang disebutkan terdahulu juga memiliki unsur-unsur khusus. 
Musyawarah nasional III persahi: the rule of law, Desember 1966 merumuskan prinsip-prinsip negara hukum Pancasila terdiri dari:

a. Pengakuan dan perlindungan hak asasi yang mengandung persamaan dalam bidang politik, hukum, sosial, ekonomi, kultural dan pendidikan.

b. Peradilan yang bebas dan tidak memihak, tidak terpengaruh oleh sesuatu kekuasaan/kekuatan lain apapun.

c. Jaminan kepastian hukum dalam semua persoalan.

F. Negara Hukum Kesejahtraan (Welfare State) dan Konsep Dasar Negara Hukum Indonesia

Teori negara hukum kesejahteraan merupakan perpaduan antara konsep negara hukum dan negara kesejahteraan. Menurut Burkens, ${ }^{14}$ negara hukum ialah negara yang menempatkan hukum sebagai dasar kekuasaannya dalam penyelenggaraan kekuasaan tersebut dalam segala bentuknya dilakukan di bawah kekuasaan hukum. ${ }^{15}$ Sedangkan konsep negara kesejahteraan, menurut Bagir Manan, bahwa negara atau pemerintah tidak semata-mata sebagai penjaga keamanan atau ketertiban masyarakat, tetapi pemikul utama tanggung jawab mewujudkan keadilan sosial, kesejahteraan umum dan sebesar-besarnya kemakmuran rakyat.

Konsep rechstaat mengutamakan prinsip wetmatigheid yang kemudian menjadi rechtmatigheid.

Unsur-unsur rechtsstaat:

1) Adanya perlindungan terhadap hak-hak asasi manusia (HAM).

2) Adanya pemisahan dan pembagian kekuasaan negara untuk menjamin perlindungan HAM.

3) Pemerintahan berdasarkan peraturan.

14 Bagir Manan, Politik Perundang-Undangan dalam Rangka Mengantisipasi Liberalisasi Otonomi, FH-UNILA, Bandar Lampung, 1996, Hal 16.

15 Mochtar, Kusuamatmadja, “Pemantapan Cita Hukum dan Asas-asas Hukum Nasional di Masa Kini dan Masa yang Akan Datang", Makalah, Jakarta, Hal 1. 
4) Adanya peradilan administrasi.

Dari uraian unsur-unsur rechtsstaat maka dapat dikaitkan dengan konsep perlindungan hukum, sebab konsep rechsstaat tersebut tidak lepas dari gagasan untuk memberi pengakuan dan perlindungan terhadap hak asasi manusia. Dengan demikian rechsstaat memiliki inti upaya memberikan perlindungan pada hak-hak kebebasan sipil dari warga negara, berkenaan dengan perlindungan terhadap hak-hak dasar yang sekarang lebih populer dengan HAM, yang konsekuensi logisnya harus diadakan pemisahan atau pembagian kekuasaan di dalam negara. Sebab dengan pemisahan atau pembagian kekuasaan di dalam negara, pelanggaran dapat dicegah atau paling tidak dapat diminimalkan. Disamping itu konsep rechsstaat menginginkan adanya perlindungan bagi hak asasi manusia melalui pelembagaan peradilan yang independen. Pada konsep rechsstaat terdapat lembaga peradilan administrasi yang merupakan lingkungan peradilan yang berdiri sendiri.

Negara anglo saxon tidak mengenal negara hukum atau rechsstaat, tetapi mengenal atau menganut apa yang disebut dengan "the rule of the law" atau pemerintahan oleh hukum atau government of judiciary.

Menurut A.V.Dicey, negara hukum harus mempunyai 3 unsur pokok:

1. Supremacy of law

Dalam suatu negara hukum, maka kedudukan hukum merupakan posisi tertinggi, kekuasaan harus tunduk pada hukum bukan sebaliknya hukum tunduk pada kekuasaan. Bila hukum tunduk pada kekuasaan, maka kekuasaan dapat membatalkan hukum, dengan kata lain hukum dijadikan alat untuk membenarkan kekuasaan. Hukum harus menjadi "tujuan" untung melindungi kepentingan rakyat.

2. Equality before the law

Dalam negara hukum kedudukan penguasa dengan rakyat dimata hukum adalah sama (sederajat), yang membedakan adalah fungsinya, 
yakni pemerintah berfungsi mengatur dan rakyat yang diatur. Baik yang mengatur maupun yang diatur pedomannya satu, yaitu undangundang. Bila tidak ada persamaan hukum, maka orang yang mempunyai kekuasaan akan merasa kebal hukum. Pada prinsipnya equality before the law adalah tidak ada tempat bagi backing yang salah, melainkan undang-undang merupakan backing terhadap yang benar.

\section{Human rights}

Human right, meliputi 3 hal pokok, yaitu:

a) The rights to personal freedom (kemerdekaan pribadi), yaitu untuk melakukan sesuatu yang dianggap baik bagi dirinya, tanpa merugikan orang lain.

b) The rights to freedom of discussion (kemerdekaan berdiskusi), yaitu hak untuk mengemukakan pendapat dan mengkritik, dengan ketentuan yang bersangkutan juga harus bersedia mendengarkan orang lain dan bersedia menerima kritikan orang lain.

c) The rights to public meeting (kemerdekaan mengadakan rapat), kebebasan ini harus dibatasi jangan sampai menimbulkan kekacauan atau memprovokasi.

\section{SIMPULAN}

Konsep rechstaat mengutamakan prinsip wetmatigheid yang kemudian menjadi rechtmatigheid. Unsur-unsur rechtsstaat: 1) adanya perlindungan terhadap hak-hak asasi manusia (HAM). 2) adanya pemisahan dan pembagian kekuasaan negara untuk menjamin perlindungan HAM. 3) pemerintahan berdasarkan peraturan. Dan 4) adanya peradilan administrasi. Akan tetapi pada aspek implementatif negara hukum dimaksud belum terlaksana dengan baik dan komprehensif 


\section{DAFTAR PUSTAKA}

Abdul Aziz Hakim, 2011, Negara Hukum dan Demokrasi, Pustaka Pelajar, Yogyakarta.

Amirudin dan Zaenal Asikin, 2004, Pengantar Metode Penelitian Hukum, PT. Rajawali Grafindo Persada. Jakarta.

Ni Matul Huda, 2005, Negara Hukum dan Demokrasi \& Judicial Review UII Press, Yogyakarta.

S. F Marbun, 2011, Peradilan Administratif Negara dan Upaya Administratif di Indonesia, UII Press, Yogyakartra.

Moh. Kusnardi dan Bintan Saragih, 2000, Ilmu Negara. Gaya Media. Jakarta.

Tahir Azhary, 1992, Negara Hukum, Bulan Bintang, Jakarta.

Sugan Wirananggapati dkk, 1992, Sejarah Nasional Indonesia dan Dunia. PT

Galaxy Puspa Mega. Jakarta.

Bagir Manan, 1996, Politik Perundang-Undangan dalam Rangka Mengantisipasi Liberalisasi Otonomi, FH-UNILA, Bandar Lampung.

Mochtar Kusumaatmadja, Pemantapan Cita Hukum dan Asas-asas Hukum Nasional di Masa Kini dan Masa yang akan Datang, Makalah, Jakarta.

Koko Kosidin, 1997, Perlindungan Hukum bagi Tenaga Kerja di Indonesia, Disertasi Universitas Padjajaran, Bandung. 